UDK $577.1: 61$

ISSN 1452-8258

J Med Biochem 40: 115-128, 2021

Review paper

Revijski rad

\title{
ROLE OF BIOCHEMICAL MARKERS IN THE MONITORING OF COVID-19 PATIENTS
}

\author{
ZNAČAJ BIOHEMIJSKIH MARKERA ZA PRAĆENJE COVID-19 PACIJENATA \\ Pablo Letelier1, Nicole Encina1 , Pablo Morales ${ }^{1}$, Alejandra Riffo 1, Halett Silva1, \\ Ismael Riquelme², Neftalí Guzmán ${ }^{1}$ \\ ${ }^{1}$ Precision Health Research Laboratory, Departamento de Procesos Diagnósticos y Evaluación, \\ Facultad de Ciencias de la Salud, Universidad Católica de Temuco, Chile \\ ${ }^{2}$ Instituto de Ciencias Biomédicas, Facultad de Ciencias de la Salud, Universidad Autónoma de Chile, Chile
}

\begin{abstract}
Summary
COVID-19 is an infectious disease caused by the SARSCoV-2 virus, which has given rise to a global sanitary emergency. The clinical characteristics of COVID-19 are varied and can range from an asymptomatic infection to a mild to severe pneumonia. Recent studies have shown that different laboratory parameters become altered in these patients, and as such are useful as biomarkers to assess the progression of the disease and categorize patients that may present a severe and/or fatal clinical condition. This review analyzes biochemical and immunological markers that become altered in COVID-19 patients and their impact on different organs at a hepatic, cardiac, renal and pancreatic level, as well as markers of inflammation, analyzing their implications in the evolution of the disease.
\end{abstract}

Keywords: coronavirus disease, COVID-19, SARS-CoV2, laboratory diagnosis, biomarkers

\begin{abstract}
Kratak sadržaj
COVID-19 je infektivno oboljenje izazvano SARS CoV-2 virusom, koje je dovelo do globalne pandemije. Kliničke karakteristike COVID-19 su različite i kreću se od asimptotske infekcije do srednje ili teške pneumonije. Nedavne studije ukazuju da se različiti laboratorijski parametri menjanju kod ovih pacijenata, i kao takvi su korisni kao biomarkeri za praćenje napredovanja oboljenja i kategorizaciju pacijenata koji mogu imati teška i/ili fatalna klinička stanja. U ovom radu su analizirani biohemijski i imunološki markeri koji se menjaju kod COVID-19 pacijenata i pokazatelj su stanja različitih organa kao što su jetra, srce, bubrezi, pankreas, i koriste se kao markeri inflamacije, a za potrebe procene napredovanja i toka oboljenja.
\end{abstract}

Ključne reči: korona virus oboljenje, COVID-19, SARSCoV-2, laboratorijska dijagnostika, biomarkeri
Address for correspondence:

Pablo Letelier, PhD,

Precision Health Research Laboratory,

Departamento de Procesos Diagnósticos y

Evaluación, Facultad de Ciencias de la Salud,

Universidad Católica de Temuco, Chile

+56452205582

e-mail: pletelier@uct.cl
List of abbreviations: ACE, angiotensin-converting enzyme; ACE2, angiotensin Il-converting enzyme; ALT, alanine aminotransferase; ARDS, acute respiratory distress syndrome; $A R I$, acute renal insufficiency; $A R L$, acute renal injury; AST, aspartate aminotransferase; $B U N$, blood urea nitrogen; CK-MB, creatine kinase-MB; COVID-19, 2019 coronavirus disease; CRP, C-reactive protein; $C T$, computed tomography; DIC, disseminated intravascular coagulation; eGFR, estimated glomerular filtration rate; ESRD, end-stage renal disease; G-CSF, several other biomarkers such as granulocyte colony-stimulating factor; hs-CRP, high-sensitivity C-reactive protein; hsTn, high-sensitivity troponin; ICU, Intensive Care Unit; IFN, Interferon- 


\section{Introduction}

In December 2019, the city of Wuhan in China became the epicenter of unexplainable cases of pneumonia, which in January 2020 were identified as a new coronavirus, turning rapidly into a major problem of public health worldwide (1). This pathogen, corresponding to a beta coronavirus, is made up of single chains of positive RNA belonging to the large Coronaviridae subfamily and has the ability to infect mammals and other animals (2). The 2019 coronavirus disease (COVID-19) is caused by the coronavirus 2 of the severe acute respiratory syndrome (SARS-CoV-2) (3), which spread rapidly all over the world and was declared by the World Health Organization (WHO) as a pandemic on 11 March 2020 (4).

The entry path of SARS coronavirus into the host cells has been associated fundamentally with the angiotensin II-converting enzyme (ACE2) that, when is located in the membrane of the cell, can function as a receptor for certain proteins expressed by this virus. The tissue location of ACE2 would be related to how the disease affects different tissues or organs (5). This protein is expressed predominantly in different cell types such as epithelial, pulmonary alveolar, small intestine epithelial, vascular endothelial and smooth muscle cells (5). ACE2 regulates the angiotensinrenin system, counteracting the activity of the angiotensin-converting enzyme (ACE) and having a protective effect on acute respiratory distress syndrome (ARDS). ACE2 is a type I transmembrane glycoprotein consisting of 805 amino acids and a single extracellular catalytic domain with a molecular weight of approximately $120 \mathrm{kDa}$, whereas the ACE2 coding gene is located in chromosome $X(6)$. Similar to ACE, ACE2 has two domains: the amino-terminal catalytic domain and the carboxy-terminal domain. The catalytic domain exhibits $41.8 \%$ sequence identity with the amino domain of ACE (6).

The coronavirus family contains seven viruses that can cause severe infections in human beings: HCoV-229E, HCoV-HKU1, HCoV-NL63, HCoVOC43, SARS-CoV, MERS-CoV and SARS-CoV-2. These are zoonotic viruses with single-stranded enveloped RNA, spherical in shape with pronounced protrusions of spike glycoproteins, called protein S, on the surface of the envelope, in addition to structural proteins including the envelope (protein $E$ ), the matrix (protein M), and the nucleocapsid (protein N) $(7,8)$. The spikes $(S)$ glycoproteins of the virus act as binding proteins and are thus highly important because they allow the entry of this virus into the target cell. Protein $S$ is trimeric, equipped with subunits S1 and S2, where S1 carries the receptor-binding domain (RBD) that interacts with the target cell and binds with an ACE2 domain (9). When interacting it produces a greater concentration of angiotensin II and can unleash local vasoconstriction. It also binds with pulmonary and blood vessel cell receptors, which in severe cases leads to pulmonary compromise and diffuse alveolar damage, coating them with a membrane and causing respiratory distress and fibrosis (10).

COVID-19 is diagnosed through laboratory tests in patients with epidemiological history and clinical symptoms, together with radiological examinations $(11,12)$. The COVID-19 disease has different clinical presentations, ranging from asymptomatic to mild, moderate or severe symptoms, with or without the presence of pneumonia (13). Fever and coughing are the most common symptoms at a global level (14).

The accumulated evidence has shown that many biochemical parameters become altered in COVID-19 patients, and this has been correlated with the severity of the disease and in some cases associated with the prognosis of the patients. The laboratory parameters together with other demographic and clinical data of patients could allow them to be categorized in the initial stages, thus identifying people who will become critically ill and making it possible to improve their clinical care and seek adequate therapeutic strategies. This paper focuses on analyzing the importance of biochemical biomarkers (hepatic, cardiac, renal, pancreatic and inflammatory) in COVID19 patients and their implications in the evolution of the disease.

\section{Role of the laboratory in the assessment of biochemical parameters in COVID-19 patients}

Clinical laboratories play an essential role in the detection of the virus as well as to the follow-up of patients (monitoring their evolution) and epidemiological surveillance via the determination of serological markers in their systems (15). Laboratory tests validated for SARS-CoV-2 are crucial for the timely management of COVID-19 because they support the clinical decision-making process for controlling infections and detecting asymptomatic cases. This expedites speedy isolation, adequate treatment and consequently reduces contagion rates (16).

inducible protein 10; IL-, Interleukin; LDH, Lactate dehydrogenase enzyme; MAS, macrophage activation syndrome; MCP-1, monocyte chemoattractant protein 1; MOF, multiple organ failure; N8R, Neutrophil-to-CD8+ T cell ratio; NLR, Neutrophil-tolymphocyte ratio; NT-proBNP, N-terminal pro B type natriuretic peptide; OR, Odds ratio; RAAS, renin-angiotensin-aldosterone system; RBD, receptor-binding domain; SARS-CoV-2, coronavirus 2 of the severe acute respiratory syndrome; TBIL, total serum bilirubin; TNF, tumor necrosis factor; ULN, upper limit of normal 
Many laboratory parameters make it possible to assess the severity of the disease and predict the risk of it evolving toward more serious afflictions such as acute respiratory distress syndrome (ARDS), disseminated intravascular coagulation (DIC) and multiple organ failure (MOF) (17). Some parameters for which an unfavorable course of the disease has been described are absolute neutrophilia, thrombocytopenia, hypoalbuminemia, the elevation of liver enzymes, creatinine and nonspecific inflammatory markers such as C-reactive protein (CRP) and Interleukin 6 (IL-6) (18). Not with standing the above, the main progression predictors described are lymphopenia, elevated D-dimer and hyperferritinemia, although it is also necessary to consider LDH, CPK and troponin in the marker panel (19).

\section{Inflammatory response markers}

Table I presents the laboratory findings of parameters associated with inflammation when admitting patients diagnosed with COVID-19, depending on the severity of the clinical condition. An exacerbated reaction of the immune system in COVID-19 patients provokes an inflammatory response called "cytokine storm «, which cause damage to different tissues contributing to worsening the condition of the patient $(20,21)$. Lymphopenia and elevated proinflammatory cytokines have been reported to be frequent in severe cases of COVID-19 in comparison with milder cases, with higher serum concentrations of IL6, IL10, IL2 and IFN- $\gamma$ present in severe cases (22). In this context, it has been observed that the neutrophil-to-lymphocyte ratio (NLR) and neutrophil-to-CD8 + T cell ratio (N8R) can be useful as diagnostic factors in seriously ill patients (22). In addition, it was established that cytokines (IL2 , IL-4, IL-10, IFN- $\gamma$ and TNF- $\alpha$ ), except for IL-6, show maximum levels in serum 3 to 6 days after the onset of the disease. Both the IL-6 and IL-10 levels displayed significant increases in the seriously sick group in comparison with the milder cases and significant increases in the serum levels of IL-2 and IFN- $\gamma$ were only observed in the seriously ill group 4 to 6 days after the onset of the disease (22).

Huang et al. (23) established that the plasma concentrations of IL2, IL7, IL10, GCSF, IP10, MCP1, MIP1A, and TNF- $\alpha$ were higher in Intensive Care Unit (ICU) patients in comparison with non-ICU patients. In turn, Qin et al. (24) reported that a majority of severe cases showed an elevation of biomarkers related to infection (procalcitonin, serum ferritin and CRP) and inflammatory cytokines (IL-2R, IL-6, IL-8, IL-10 and TNF- $\alpha$ ).

C-reactive protein is a plasma protein that is synthesized by the liver and induced by different inflammatory mediators such as IL-6. Despite being nonspecific, it is used clinically as a biomarker for different inflammatory complaints, and an increase in its levels is associated with greater severity of the disease (25). This protein can activate the complement through the classic route and has the ability to modulate the function of phagocytic cells, properties that suggest it would play a role in the opsonization of infectious agents and damaged cells (26). In a study where the levels of C-reactive protein in COVID-19 patients were evaluated and categorized in four stages according to the computed tomography (CT) findings: initial (3 days), progression ( 7 days), peak (12 days) and recovery (16 days), the results of the seriously ill group $(n=6)$ presented higher levels of CRP in the progression stage than the milder group $(n=21)$, but decreased without statistically significant differences in the peak and recovery stages (27). Moreover, Liu et al. (28) established that the C-reactive protein was significantly higher in the progression group than in the recovery/stabilization group (38.9 vs. $10.6 \mathrm{mg} / \mathrm{L}$ ). In contrast, albumin diminished significantly in the progression group $(41.27 \mathrm{~g} / \mathrm{L})$ in comparison with the recovery group $(36.62 \mathrm{~g} / \mathrm{L})$ (28). In the multivariate analysis both the albumin (Odds ratio, OR) 7.353, confidence interval $(\mathrm{Cl})$ 95\%: 1.098-50.000; P level $=0.003)$ and CRP (OR, 10.530; CI95\%: 1.224-34.701, $P=0.028$ ) were risk factors for the progression of the disease. The plasma concentrations of these proteins in the acute phase (albumin, CRP) become modified by at least $25 \%$ in response to certain cytokines produced during different types of inflammatory processes where some degree of tissue damage is involved $(29,30)$.

Furthermore, it has been reported that the elevation of the lactate dehydrogenase enzyme (LDH) used as a marker of lung tissue damage, is one of the most frequent biochemical anomalies in COVID-19 patients on admission to the hospital (15). Many studies have shown that patients with mild infection have $\mathrm{LDH}$ values within the reference ranges, unlike patients in critical condition $(22,31,32)$, where a significant difference in the magnitude of the alteration is observed in the seriously ill patients $(23,33-35)$.

Yuan et al. (36) revealed that in the first six days of hospitalization, those patients in severe clinical conditions showed significantly higher levels of IL-6 and LDH in serum than those of the moderate group, which descended drastically around day 6 to 9 in both groups of patients. Interestingly, the decrease of serum levels of LDH and CK was correlated with the elimination of viral mRNA, suggesting that the constitutive reduction in the levels of $\mathrm{LDH}$ or $\mathrm{CK}$ is likely to predict a favorable response to the course of infection in COVID-19 patients (36).

In patients with severe pneumonia, the initial infectious condition precedes (between 5 and 9 days) a state of systemic inflammatory hyper reactivity, probably favored by the "cytokine storm « or macrophage activation syndrome (MAS). This typical- 
Table I Laboratory parameters related to inflammation on admission of patients diagnosed with COVID-19, according to the severity of the disease.

\begin{tabular}{|c|c|c|c|c|c|c|c|c|}
\hline \multirow{2}{*}{ Parameter } & \multirow{2}{*}{$\begin{array}{l}\mathrm{N}^{\circ} \text { of } \\
\text { cases }\end{array}$} & \multirow{2}{*}{$\begin{array}{l}\text { Reference } \\
\text { range }\end{array}$} & \multicolumn{4}{|c|}{ Severity of the Disease } & \multirow{2}{*}{$\begin{array}{c}P \\
\text { value }\end{array}$} & \multirow[t]{2}{*}{ Reference } \\
\hline & & & $\begin{array}{l}\text { Total } \\
\text { cases }\end{array}$ & $\begin{array}{l}\text { Mild } \\
\text { cases }\end{array}$ & $\begin{array}{c}\text { Serious } \\
\text { cases }\end{array}$ & \begin{tabular}{|c|} 
Other \\
classifications
\end{tabular} & & \\
\hline \multirow{10}{*}{$\begin{array}{l}\text { Lactate dehydrogenase } \\
\text { (U/L) }\end{array}$} & 138 & $125-243$ & 261 & 212 & 435 & & $S$ & (32) \\
\hline & 99 & $120-250$ & 336 & - & - & & - & (41) \\
\hline & 41 & $\leq 245$ & 286 & 281 & 400 & & $S$ & (23) \\
\hline & 40 & - & 304 & 221 & 462 & & NS & (22) \\
\hline & 12 & $114-240$ & 605 & - & - & & - & (42) \\
\hline & 19 & $120-250$ & 256 & - & - & & - & (43) \\
\hline & 174 & $\begin{array}{l}M: 135-225 \\
F: 135-214\end{array}$ & 267 & 246 & 336 & & - & (34) \\
\hline & 701 & - & 377 & - & - & $\begin{array}{l}\text { NLF: } 364 ; \\
\text { ALF: } 458\end{array}$ & $S$ & (33) \\
\hline & 150 & $120-250$ & - & - & - & $\begin{array}{l}\text { R: } 289 ; \\
\text { D: } 906\end{array}$ & S & (35) \\
\hline & 148 & - & 224 & - & - & $\begin{array}{l}\text { NLF: } 201 ; \\
\text { ALF: } 257\end{array}$ & $\mathrm{~S}$ & (31) \\
\hline \multirow{9}{*}{$\begin{array}{l}\text { C-reactive protein } \\
(\mathrm{mg} / \mathrm{L})\end{array}$} & 73 & $0-5.0$ & 51.4 & - & - & & - & (41) \\
\hline & 12 & $<10$ & 41.1 & - & - & & - & $(42)$ \\
\hline & 19 & $0-4$ & 26.5 & - & - & & - & (43) \\
\hline & 136 & $0-5$ & 34.2 & 28.7 & 46.6 & & $S$ & (44) \\
\hline & 452 & $0-1.0$ & 44.1 & 33.2 & 57.9 & & $S$ & (24) \\
\hline & 40 & - & 38.1 & 7.6 & 62 & & - & (22) \\
\hline & 157 & $<1$ & 31.9 & 33.95 & 19.31 & & - & (34) \\
\hline & 150 & $0-5.0$ & - & - & - & $\begin{array}{l}\text { R: } 34 ; \\
\text { D: } 126\end{array}$ & $S$ & (35) \\
\hline & 148 & - & 17.7 & - & - & $\begin{array}{l}\text { NLF: } 13 ; \\
\text { ALF: } 25\end{array}$ & $S$ & (31) \\
\hline \multirow{7}{*}{$\begin{array}{l}\text { Procalcitonin } \\
(\mathrm{ng} / \mathrm{mL})\end{array}$} & 138 & $<0.05$ & 49 & 22 & 27 & & $S$ & (32) \\
\hline & 99 & $0-5.0$ & 0.5 & - & - & & - & (41) \\
\hline & 41 & $<0.1$ & 0.1 & 0.1 & 0.1 & & - & (23) \\
\hline & 12 & $0-0.5$ & 0.81 & - & - & & - & (42) \\
\hline & 118 & $0-5$ & 0.07 & 0.05 & 0.1 & & $S$ & (44) \\
\hline & 452 & 0-0.05 & 0.1 & 0.05 & 0.1 & & $S$ & (24) \\
\hline & 148 & - & 0.3 & & & $\begin{array}{l}\text { NLF: } 0.02 ; \\
\text { ALF: } 0.06\end{array}$ & $S$ & (31) \\
\hline $\begin{array}{l}\text { Interleukin-1 } \beta \\
(\mathrm{pg} / \mathrm{mL})\end{array}$ & 452 & $0-5.0$ & 5.0 & 5.0 & 5.0 & & NS & (24) \\
\hline \multirow{4}{*}{$\begin{array}{l}\text { Interleukin-6 } \\
(\mathrm{pg} / \mathrm{mL})\end{array}$} & 99 & $0-7$ & 7.9 & - & - & & - & (41) \\
\hline & 7 & $0-7$ & 19.3 & - & - & & S & (43) \\
\hline & 452 & $0-7$ & 21.0 & 13.3 & 25.2 & & $S$ & (24) \\
\hline & 150 & $0-7$ & - & - & - & $\begin{array}{l}\text { R: } 6.8 ; \\
\text { D: } 11.4\end{array}$ & & (35) \\
\hline Interleukin-10 (pg/mL) & 452 & $0-9.1$ & 5.4 & 5.0 & 6.6 & & $S$ & (24) \\
\hline
\end{tabular}

Each value of the table represents the mean, median; -: Data not available; M: Male; F: Female; S: Statistically significant; NS: Not statistically significant $(+)$ : proteinuria or hematuria,+++ or +++

Other classifications: R: Recovered; D: Deceased; NLF: Normal liver function; ALF: Abnormal liver function 
ly occurs in subjects with ARDS, where the exacerbated CRP increase and hyper ferrfitinemia are key for diagnosing MAS and are elevated in many serious cases of pneumonia due to COVID-19 (37). The low survival rate of ARDS has been related to a sustained elevation of IL-6 and IL-1 (37). This hyper inflammatory state is characterized by increased acute phase reactants associated with an exacerbated increment of pro-inflammatory cytokines such as IL-6, clearly elevated in non-survivors in comparison with those who survive throughout the clinical course and increasing with the deterioration of the disease (38). In the univariate analysis, it was possible to associate it with a greater probability of in-hospital death in patients with elevated LDH, IL-6 and procalcitonin (38), where it was observed that LDH increases in both groups (survivors and non-survivors) in the early stage of the disease, but in this study decreased as of day 13 in the survivors (38).

Extra pulmonary systemic hyper inflammation syndrome occurs in a minority of infected patients and is characterized by the presence of so-called "cytokine storm", induced by increased levels of cytokines and interleukins such as IL-2, IL-6, IL-7, IL10 and tumor necrosis factor (TNF) $\alpha$, together with several other biomarkers such as granulocyte colonystimulating factor (G-CSF), interferon-inducible protein 10 (IFN), monocyte chemoattractant protein 1 (MCP-1) and inflammatory macrophage protein 1- $\alpha$. On the other hand, this pathology is also characterized by a decrease of CD4 + and $C D 8+T$ cells, and of the IFN- $\gamma$ expression by CD4 $+\mathrm{T}$ cells (39). Moreover, higher levels of G-CSF have been also found in ICU patients, which is associated significantly with severe disease (40).

\section{Cardiac markers}

The risk factors associated with cardiac events during the COVID-19 disease include advanced age, preexisting cardiovascular disease and greater severity in the presentation of pneumonia. The elements through which these events occur include: 1) systemic mechanisms such as pro-inflammatory responses of the atherosclerosis-mediating cytokines (IL6, IL-7, IL-22, CXCL10), which contribute directly to plaque rupture through local inflammation; 2 ) induction of pro-coagulation factors; and, 3) hemodynamic changes predisposing to ischemia and thrombosis (38). For this reason, the comorbidities and direct and indirect cardiac damage contribute to producing slight increases in the high-sensitivity troponin I markers (hsTn) or the $\mathrm{N}$-terminal pro $\mathrm{B}$ type natriuretic peptide (NT-proBNP) in hospitalized patients (45).

Table II presents the laboratory findings of parameters associated with cardiac, hepatic and renal function on the admission of patients diagnosed with COVID-19, according to the severity of the clinical condition. ACE2 expression has been detected in cardiac endothelial cells, vascular smooth muscle cells and cardiomyocytes (46), suggesting that SARS-CoV2 could enter the host cells via the binding of the spike protein with ACE2, affecting cardiovascular homeostasis through the renin-angiotensin-aldosterone system (RAAS) and generating a myocardial injury (47). Previously, cardiac tissue biopsy had revealed the presence of SARS-CoV-1 in 35\% of deceased subjects (48).

A meta-analysis of 4,189 patients in 28 studies established that seriously ill COVID-19 patients presented significantly higher levels of troponin, creatine kinase-MB (CK-MB), myoglobin and NT-proBNP. Acute cardiac injury (troponin elevation), was more frequent in patients with serious conditions in comparison with their milder counterparts. Predominantly, hsTnl and NT-proBNP levels increased during the course of the hospitalization solely in non-survivors (49).

Churchill et al. (50) evaluated the prevalence and reversibility of left ventricular dysfunction using echocardiography, including 93 patients with a comorbidity history of hypertension (60\%), diabetes mellitus (41\%) and obesity (50\%). $88 \%$ of the patients had to be admitted to the ICU with the support of mechanical ventilation and $71 \%$ required vasopressor support. In these patients $(n=93)$ the median of highsensitivity troponin (hsTn) was $51 \mathrm{ng} / \mathrm{L}$ and that of the natriuretic peptide was $1.643 \mathrm{pg} / \mathrm{mL}$. Of the subset of 50 patients with a troponin level of $50 \mathrm{ng} / \mathrm{L}$, $48 \%$ evidenced left ventricular dysfunction (50).

In turn, Huang et al. (23) found that hsTnl increased substantially in five patients $(12.2 \%)$, who were diagnosed with cardiac injury related to the virus. It was also observed that the aspartate aminotransferase (AST) enzyme increased in $62 \%$ of the ICU patients compared to an increase in only $25 \%$ of those patients not in the ICU (23). In another 138 patients, the average levels of hsTnl were within the reference range, although they increased in ICU patients (32). It has also been reported that the maximum level of cardiac troponin I $(0.00 \mathrm{ng} / \mathrm{L}$ vs. 0.56 $\mathrm{ng} / \mathrm{L} ; \mathrm{p}<0.01)$ and the maximum levels of NTproBNP (301.2 ng/L vs $2887.5 \mathrm{ng} / \mathrm{L} ; \mathrm{P}<0.01$ ) and creatine kinase $M B(1.3 \mathrm{ng} / \mathrm{mL}$ vs $3.9 \mathrm{ng} / \mathrm{mL}$; $\mathrm{p}<0.01$ ) were higher in patients admitted to the ICU or who required mechanical ventilation, extracorporeal membrane oxygenation (ECMO) or who died. In addition, the Cox proportional hazard ratio analysis showed that the maximum level of cardiac troponin I and the maximum level of NT-proBNP have presented significantly higher risk ratios $(8.9(\mathrm{Cl} 95 \%$ : $1.9-$ 40.6; $\mathrm{p}<0.01)$ and $1.2(95 \% \mathrm{Cl}: 1.1-1.3 ; \mathrm{p}<0.01)$ ), respectively (51). Moreover, in the univariate analysis Zhou et al. (38) associated greater likelihood of death in patients with elevated ALT, high-sensitivity cardiac troponin I and creatine kinase, while in the group of 
Table II Laboratory parameters related to cardiac, hepatic and renal function on the admission of patients diagnosed with COVID19 , according to the severity of the disease.

\begin{tabular}{|c|c|c|c|c|c|c|c|c|}
\hline \multirow[b]{2}{*}{ Parameter } & \multirow{2}{*}{$\begin{array}{l}\mathrm{N}^{\circ} \text { of } \\
\text { cases }\end{array}$} & \multirow{2}{*}{$\begin{array}{l}\text { Reference } \\
\text { range }\end{array}$} & \multicolumn{4}{|c|}{ Severity of the disease } & \multirow{2}{*}{$\begin{array}{c}P \\
\text { value }\end{array}$} & \multirow[b]{2}{*}{ Reference } \\
\hline & & & $\begin{array}{l}\text { Total } \\
\text { cases }\end{array}$ & $\begin{array}{l}\text { Mild } \\
\text { cases }\end{array}$ & $\begin{array}{l}\text { Serious } \\
\text { cases }\end{array}$ & $\begin{array}{c}\text { Other } \\
\text { classifications }\end{array}$ & & \\
\hline \multirow{3}{*}{$\begin{array}{l}\text { Troponin I } \\
(\mathrm{pg} / \mathrm{mL})\end{array}$} & 138 & $<26.2$ & 6.4 & 5.1 & 11 & & $S$ & (32) \\
\hline & 150 & $2-28$ & - & & & R: $3.5 ; \mathrm{D}: 30.3$ & $S$ & (35) \\
\hline & 41 & $\leq 28$ & 3.4 & 3.5 & 3.3 & & - & $(23)$ \\
\hline Troponin I ( $\mu \mathrm{g} / \mathrm{mL})$ & 12 & $0-0.1$ & 0.95 & - & - & & - & $(42)$ \\
\hline Creatine kinase-MB (U/L) & 138 & $<25$ & 14 & 13 & 18 & & $S$ & $(32)$ \\
\hline Creatine kinase-MB (ng/mL) & 12 & $0-2.37$ & 2.0 & - & - & & - & $(42)$ \\
\hline \multirow[t]{4}{*}{ Myoglobin (ng/mL) } & 99 & $0-146.9$ & 67.9 & - & - & & - & (41) \\
\hline & 12 & $0-110$ & 43.9 & - & - & & - & $(42)$ \\
\hline & 65 & $0-106$ & 58.6 & 21.6 & 63.4 & & - & (34) \\
\hline & 150 & $0-146.9$ & - & & & R: 77.7; D: 258.9 & $S$ & (35) \\
\hline Natriuretic peptide (pmol/L) & 4 & $0-23.1$ & 43.9 & - & - & & - & $(42)$ \\
\hline \multirow{11}{*}{$\begin{array}{l}\text { Alanin } \\
\text { aminotransferase (U/L) }\end{array}$} & 138 & $9-50$ & 24 & 23 & 35 & & $\mathrm{~S}$ & (32) \\
\hline & 99 & $9-50$ & 39 & - & - & & - & (41) \\
\hline & 41 & - & 32 & 27 & 49 & & $S$ & $(23)$ \\
\hline & 40 & - & 22.5 & 19 & 27 & & - & $(22)$ \\
\hline & 12 & $0-45$ & 31.6 & - & - & & - & $(42)$ \\
\hline & 105 & M: 9-50 F: 7-40 & 23.5 & 22 & 27.8 & & $S$ & (61) \\
\hline & 18 & $9-50$ & 36.4 & - & - & & - & (43) \\
\hline & 193 & M: 0-41 F: 0-33 & 20 & 19 & 21 & & - & (34) \\
\hline & 150 & $9-50$ & - & & & R: 48.7; D: 170.8 & - & (35) \\
\hline & 701 & - & 35 & & & NScr: 36; EScr: 32 & - & (33) \\
\hline & 417 & $\leq 40$ & 21 & & & $\begin{array}{c}\text { NLF: 17; } \\
\text { ALF: } 27 ; \text { LI: } 47\end{array}$ & $S$ & $(52)$ \\
\hline \multirow{11}{*}{$\begin{array}{l}\text { Aspartat } \\
\text { aminotransferase }(\mathrm{U} / \mathrm{L})\end{array}$} & 138 & $15-40$ & 31 & 29 & 52 & & $S$ & (32) \\
\hline & 99 & $15-40$ & 34 & - & - & & - & (41) \\
\hline & 41 & $\leq 40$ & 34 & 34 & 44 & & NS & (23) \\
\hline & 12 & $0-45$ & 40 & - & - & & - & $(42)$ \\
\hline & 50 & $M: 15-40 \mathrm{~F}: 13-35$ & 24.2 & 22 & 46.3 & & $S$ & (61) \\
\hline & 18 & $15-40$ & 34.9 & - & - & & - & $(43)$ \\
\hline & 193 & M: 0-40 F: 0-32 & 30 & 26 & 40 & & - & (34) \\
\hline & 40 & - & 34.1 & 25.9 & 51.2 & & - & $(22)$ \\
\hline & 150 & $15-40$ & - & & & R: 48.7; D: 288.9 & NS & (35) \\
\hline & 701 & - & 42 & & & NScr: 41; EScr: 47 & NS & (33) \\
\hline & 417 & $\leq 40$ & 26.5 & & & $\begin{array}{c}\text { NLF: 23; } \\
\text { ALF: 34; LI: } 47\end{array}$ & $S$ & $(52)$ \\
\hline \multirow{2}{*}{$\begin{array}{l}\text { Gamma-glutamyltrans- } \\
\text { peptidase }(\mathrm{U} / \mathrm{L})\end{array}$} & 14 & $7-45$ & 42.2 & - & - & & - & $(43)$ \\
\hline & 417 & $\leq 49$ & 34.1 & & & $\begin{array}{c}\text { NLF: 21; } \\
\text { ALF: 36; LI: } 135\end{array}$ & $S$ & $(52)$ \\
\hline
\end{tabular}




\begin{tabular}{|c|c|c|c|c|c|c|c|c|}
\hline \multirow[t]{3}{*}{ Total bilirubin (mmol/L) } & 138 & $5-21$ & 9.8 & 9.3 & 11.5 & & $S$ & (32) \\
\hline & 701 & - & 12 & & & NScr: 11; EScr: 21 & NS & (33) \\
\hline & 41 & - & 11.7 & 10.7 & 14 & & $\mathrm{~S}$ & (23) \\
\hline \multirow[t]{7}{*}{ Total bilirubin $(\mu \mathrm{mol} / \mathrm{L})$} & 50 & $0-18.8$ & 10.2 & 10 & 10.6 & & NS & (61) \\
\hline & 12 & $3-22$ & 8.2 & - & - & & - & $(42)$ \\
\hline & 40 & - & 10.3 & 8.8 & 13.2 & & - & $(22)$ \\
\hline & 193 & M: 0-26 F: 0-21 & 8.82 & 7.85 & 13.39 & & - & (34) \\
\hline & 99 & $0-21$ & 15 & - & - & & - & (41) \\
\hline & 150 & $0-26$ & - & & & $\mathrm{R}: 5.1 ; \mathrm{D}: 8.6$ & $\mathrm{~S}$ & (35) \\
\hline & 417 & $\leq 17.1$ & 10.9 & & & $\begin{array}{c}\text { NLF: 9; ALF: 17; } \\
\text { LI: } 17\end{array}$ & S & $(52)$ \\
\hline Alkaline phosphatase (U/L) & 417 & $\leq 135$ & 61 & & & $\begin{array}{c}\text { NLF: 59; ALF: 63; } \\
\text { IL: } 68\end{array}$ & $\mathrm{~S}$ & $(52)$ \\
\hline \multirow[t]{6}{*}{ Albumin $(\mathrm{g} / \mathrm{L})$} & 99 & $40-55$ & 31.6 & - & - & & - & (41) \\
\hline & 41 & - & 31.4 & 34.7 & 27.9 & & $\mathrm{~S}$ & (23) \\
\hline & 12 & $40-55$ & 37.7 & - & - & & - & $(42)$ \\
\hline & 49 & $40-55$ & 41.6 & 42 & 37.2 & & $S$ & (61) \\
\hline & 193 & $35-52$ & 34.2 & 35.2 & 32.6 & & - & (34) \\
\hline & 150 & $35-52$ & - & & & R: 33; D: 28.8 & $S$ & (35) \\
\hline \multirow{8}{*}{$\begin{array}{l}\text { Blood urea } \\
\text { nitrogen }(\mathrm{mmol} / \mathrm{L})\end{array}$} & 138 & $2.8-7.6$ & 4.4 & 4.0 & 5.9 & & $\mathrm{~S}$ & (32) \\
\hline & 99 & $3.6-9.5$ & 5.9 & - & - & & - & $(41)$ \\
\hline & 12 & $3.2-7.1$ & 5.4 & - & - & & - & $(42)$ \\
\hline & 87 & $2.9-8.2$ & 3.8 & 3.72 & 4.14 & & NS & (59) \\
\hline & 193 & $3.1-8$ & 4.4 & 3.9 & 6.43 & & - & (34) \\
\hline & 40 & - & 3.2 & 3.2 & 3.3 & & - & $(22)$ \\
\hline & 701 & ** & 5.7 & & & NScr: 4.8; EScr: 11 & $\mathrm{~S}$ & (33) \\
\hline & 150 & $3.1-8$ & - & & & R: 5.1; D: 8.65 & $S$ & (35) \\
\hline \multirow{9}{*}{$\begin{array}{l}\text { Serum creatinine } \\
(\mu \mathrm{mol} / \mathrm{L})\end{array}$} & 138 & $64-104$ & 72 & 71 & 80 & & $S$ & (32) \\
\hline & 99 & $57-111$ & 75.6 & - & - & & - & $(41)$ \\
\hline & 41 & $\leq 133$ & 74 & 73 & 79 & & NS & $(23)$ \\
\hline & 12 & $58-110$ & 85.6 & - & - & & - & $(42)$ \\
\hline & 40 & - & 67.3 & 64.0 & 74.2 & & - & $(22)$ \\
\hline & 87 & M: 54-133 F: 44-106 & 65.2 & 65.3 & 71 & & NS & (59) \\
\hline & 193 & M: 59-104 F:45-84 & 66 & 63 & 73 & & - & (34) \\
\hline & 701 & M: 104 F: 84 & 77 & & & NScr: 68; EScr: 132 & $S$ & (33) \\
\hline & 150 & 59-104 & - & & & R: 72.1; D: 91.2 & $\mathrm{~S}$ & (35) \\
\hline \multirow[t]{3}{*}{ Proteinuria (+) } & 83 & Negative & $35 \%$ & $28 \%$ & $58 \%$ & & & $(59)$ \\
\hline & 129 & Negative & $59 \%$ & $55 \%$ & $66 \%$ & & & (34) \\
\hline & 442 & Negative & $44 \%$ & & & $\begin{array}{l}\text { NScr: } 40 \% ; \\
\text { EScr: } 70 \%\end{array}$ & & (33) \\
\hline \multirow[t]{3}{*}{ Hematuria $(+)$} & 83 & Negative & $29 \%$ & $22 \%$ & $53 \%$ & & & (59) \\
\hline & 129 & Negative & $44 \%$ & $44 \%$ & $45 \%$ & & & (34) \\
\hline & 442 & Negative & $27 \%$ & & & $\begin{array}{l}\text { NScr: } 23 \% ; \\
\text { EScr: } 53 \%\end{array}$ & & (33) \\
\hline
\end{tabular}

Each value of the table represents the mean, median

-: not available; M: Male, F: Female; S: statistically significant difference between mild and severe cases N; S: non-significant difference between mild and severe cases (+): proteinuria or hematuria,$+++0+++$ **: upper BUN limit according to age $<60,60-80$ and $>80$ years; for men it is $8.0,9.5$ and $8.3 \mathrm{mmol} / \mathrm{L}$ respectively, and for women $7.5,8.8$ and $8.3 \mathrm{mmol} / \mathrm{L}$ respectively. Other classifications: R: Recovered; D: Dead; NScr: Normal base serum creatinine; EScr: Elevated base serum creatinine; NLF: Normal liver function; ALF: Abnormal liver function; LI: Liver injury 
non-survivors the high-sensitivity cardiac troponin I increased rapidly as of day 16 after the onset of the disease. In the same context, Deng et al. (51) established that a majority of patients had normal levels of troponin on admission but, in $37.5 \%$ of the cases, these levels increased during hospitalization particularly in those patients who then died. In fact, the troponin levels increased significantly within that week before death (51).

In the study by Chen et al. (41) it was observed that $76 \%$ of patients $(n=99)$ had an abnormal myocardial zymogram, with CK elevation in 13 patients and LDH elevation in 75 patients, one of whom also exhibited abnormal CK (6280 U/L) and $\mathrm{LDH}(740 \mathrm{U} / \mathrm{L})$.

\section{Hepatic markers}

Elevation of alanine aminotransferase (ALT), AST and total bilirubin is common in seriously ill patients, who present more frequent signs of liver dysfunction than those with milder conditions (40). In the Chen et al. (41) study, where 99 confirmed cases of COVID-19 were included, it was observed that 43 patients presented liver dysfunction, where ALT or AST rose above the reference range and, in particular, one case presented serious hepatic function damage with ALT and AST values of $7590 \mathrm{U} / \mathrm{L}$ and $1445 \mathrm{U} / \mathrm{L}$, respectively.

Cai et al. (52) established that over $90 \%$ of patients with abnormal hepatic tests were mild on admission (i.e., with $<2 \times$ upper limit of normal (ULN), and around $24 \%$ of them exhibited ALT and GGT elevations of more than three times the upper limit during hospitalization. However, the increase in AST and total serum bilirubin (TBIL) to more than 3 x ULN was moderate $(12 \%$ and $15 \%$, respectively), and no increase in ALP was found. Patients with abnormal hepatocellular or mixed type hepatic tests on admission were more likely to evolve toward a serious illness (OR 2.73; Cl 95\%: 1.19 to 6.3 and 4.44; Cl 95\%: 1.93 to 10.23 , respectively). Liver damage during hospitalization was especially associated with the use of medication such as lopinavir and ritonavir (52).

Gong et al. (25) evaluated 12 patients displaying alterations in laboratory parameters such as hypoalbuminemia, lymphopenia and neutrophilia, increased CRP and LDH, and reduced CD8+ count, concluding that the combination of hypoalbuminemia, lymphopenia and high concentrations of CRP and LDH could predict a more serious acute lung injury on admission to the hospital.

A post-mortem hepatic histopathological analysis in a 51-year-old man who died as a result of severe acute respiratory syndrome due to coronavirus, showed moderate microvesicular steatosis and mild lobular and portal activity, indicating that this liver injury could have been caused by SARS-CoV-2 infection or induced by medication (53). In addition, the inflammation mediated by the immune system, such as the cytokine storm and hypoxia associated with pneumonia could also have contributed to the liver injury, eventually producing hepatic insufficiency in seriously ill patients (54). This occurs because the hypoxia and shock induced by the complications (such as respiratory distress syndrome, systemic inflammatory response syndrome and multiple organ failure) can also cause hepatic ischemia and hypoxiareperfusion dysfunction (55). This finding correlates with previous reports of autopsies performed on patients with SARS-CoV-2 (56).

\section{Renal markers}

Reports have stated that, in the kidneys, ACE-2 is highly expressed on the brush border of the proximal tubular cells and to a lesser extent in the podocytes. In contrast, its expression in glomerular endothelial and mesangial cells has not been described (46). Renal disease in COVID-19 patients can manifest itself in the form of acute renal injury (ARL), hematuria or proteinuria, promoting a greater mortality risk. It is unclear whether ARL is due largely to hemodynamic changes and cytokine release or the direct toxicity of the virus (57).

Renal histopathological examinations on six patients who died of COVID-19 in Wuhan, China, showed deterioration of the renal function, in addition to different degrees of acute tubular necrosis, detachment of the luminal brush border and degeneration of the vacuole in different areas of the six samples. As a whole, these results established that the infection mainly induces severe acute tubular necrosis and lymphocyte infiltration. The viral antigen of the nucleocapsid protein (NP) was studied by immunohistochemistry, revealing its presence in the tubules of all the renal tissue samples (58). Although acute renal failure has been reported particularly in seriously ill patients, it has also been observed that both severe and milder cases display normal levels of serum creatinine and cystatin $C(n=178)$. Even though $23.6 \%$ of the patients showed a reduced estimated glomerular filtration rate (eGFR), only $2.8 \%$ of them exhibited a high BUN level and none presented an increase of serum creatinine. According to these results, none of the patients developed an acute renal injury or acute renal insufficiency during their entire hospitalization, regardless of their admission to the ICU (59). Interestingly, of the 83 patients without any kidney disease history who were subjected to a routine urine test when hospitalized, $45(54.2 \%)$ exhibited an abnormal result, such as proteinuria, hematuria and leukocyturia, but none presented acute renal insufficiency (ARI) throughout the study. Probably, these renal alterations may have been due to the nephro- 
toxicity of medication used before hospital admission, although the possibility that they were produced by the viral infection cannot be discarded (59). In line with other reports, a low degree of renal function damage, $7.32 \%$ (7 of 99), was also observed (41).

In contrast, an analysis of 59 cases hospitalized for COVID-19 in Wuhan (including 28 diagnosed as severe cases and 3 who died), found that $63 \%$ (32 of 51 patients) presented proteinuria, of which a large number $(64 \%)$ was found to have the detected urine protein on the first day of admission, suggesting that renal impairment was already present before or at the time of admission. 27\% (16 of 59 patients) of the patients had a high level of ureic nitrogen and the blood urea nitrogen (BUN) levels in 23 cases showed that $43 \%$ of these experienced an increase within an interval of 2 to 10 days, and 2/3 of the non-surviving patients exhibited notably high levels before their death. 19\% (11 of 59 patients) also exhibited a high level of creatinine. Lastly, the computed tomography results of all patients (100\%) revealed a radiographic abnormality in the kidneys (34).

Cheng et al., when evaluating a group of 701 hospitalized patients, showed that $44 \%$ had proteinuria and hematuria, while at least $26.7 \%$ presented hematuria on admission, with a prevalence of high creatininemia and uremia of $15.5 \%$ and $14.1 \%$, respectively. During the study period, $3.2 \%$ of the patients developed ARI (33). In addition, the Cox regression showed that the elevated levels of base serum creatinine $(>133 \mu \mathrm{mol} / \mathrm{L})$ and $\mathrm{BUN}$, plus acute kidney injury $(\mathrm{AKI})$ higher than stage 2, proteinuria of any degree and hematuria of any degree are independent risk factors of in-hospital death (33). Moreover, Wang et al. (32) reported that as the disease advanced and the clinical condition deteriorated, the levels of urea and creatinine in the blood increased progressively before death, reaching significant levels $(p<0.05)$ as of day 13 and 17 respectively after the onset of the disease. The results support the idea that kidney damage is common in COVID-19 patients and can be one of the main causes of the severity level of the disease, contributing to multiple organ failure and death (60). Therefore, monitoring of the kidney function would be fundamental in the clinical management of infected patients, as well as early treatment of renal failure with continuous therapy.

\section{Pancreatic markers}

Mild pancreatic injury has been reported in some COVID-19 patients (62), which can be explained at least partly by different mechanisms that include the direct cytopathic effects of SARS-CoV-2, as well as indirect and immune-mediated systemic inflammatory cell responses. Moreover, the SARSCoV-2 receptor of angiotensin-converting enzyme 2 is highly expressed in cells of the pancreatic islets and exocrine glands, which can cause the infection to damage the islets and result in acute diabetes (62$64)$, thus rendering the quantification of pancreatic enzymes such as amylase or lipase useful for followup purposes (62).

The post-infection pancreatic injury was analyzed in a study that included 212 patients. In mild cases, $1.85 \%$ (1 of 54) presented increased levels of amylase and lipase, where as he severe cases presented $17.91 \%$ (12 of 64 ) and $16.41 \%$ (11 of 64 ) of amylase and lipase, respectively. In computed tomography, 5 seriously ill patients (7.46\%) exhibited changes, mainly focal enlargement of the pancreas or dilation of the pancreatic duct, without acute necrosis (65). In this context, a study described the presence of acute pancreatitis associated with SARS-CoV-2 in members of a family, ruling out other causes of pancreatitis. In one of the cases (a 47-year-old woman) pancreatic amylase was $173 \mathrm{U} / \mathrm{L}$ on admission, rising rapidly to $>1500 \mathrm{U} / \mathrm{L}$ after 11 hours. In a second case (68-year-old woman), the amylase level increased from $85 \mathrm{U} / \mathrm{L}$ on admission day to $934 \mathrm{U} / \mathrm{L}$ on day six, and the modified Glasgow acute pancreatitis severity score was 5 points, consistent with severe acute pancreatitis (66).

Wang et al. (62) reported that $17 \%$ of patients $(n=52)$ with pneumonia due to COVID-19 showed high values of amylase or lipase, with five patients presenting underlying disorders such as hypertension, diabetes and heart disease. It is known that an elevation in pancreatic enzymes can be produced by other gastrointestinal disorders, and these have also been reported in COVID-19 patients (67), which led DeMadaria et al. (68) to suggest that pancreatic injury in COVID-19 patients be established based on imaging criteria such as computed tomography or magnetic resonance.

\section{Discussion}

COVID-19 constitutes a major public health problem at a global level and is related to multiple complications that affect both the health of patients and the associated health care costs. For this reason, clinical laboratories can contribute to establishing biomarkers that would make it possible to stratify the risk of patients evolving toward more serious conditions, thus expediting clinical decision making $(32,69)$. Although predisposing factors have been defined (gender, risk ages and association with pathologies such as obesity, diabetes and hypertension) (38), it is fundamental to use biomarkers that would allow a distinction to be made regarding the progression of the disease and anticipate which patients could require advanced medical procedures, thus making possible a focalized use of clinical resources.

The available evidence shows that patients with severe and critical cases present various alterations in 
their laboratory parameters (32), and in some cases rapidly evolve toward ARDS and septic shock followed by multiple organ failure (41). In this context, high levels of IL- 6 and increased concentrations of highsensitivity troponin I have been described as frequent in seriously ill COVID-19 patients (70).

Kidney function biomarkers such as serum creatinine were in general observed to be within the reference range $(22,23,32,34,35,41,42,59)$ and no statistically significant differences were found between the mean values of patients with mild and severe conditions on admission (Table II). During the time of hospitalization, however, it was observed that the non-surviving patients had a progressive increase (approximately as of day 10 after admission) above the reference range, reaching a peak a few days before they died. BUN levels behaved similarly, increasing during the hospitalization period in seriously ill patients. Therefore, these parameters could be used to assess the prognosis of patients in the course of their hospitalization. Renal dysfunction in nonsevere COVID-19 cases was minor and was not diagnosed as ARI, unlike patients with severe cases, where 43 out of 65 were diagnosed with ARI (34). Patients with end-stage renal disease (ESRD) are particularly vulnerable to severe COVID-19 due to the advanced age and high frequency of comorbidity such as diabetes and hypertension in this population (57).

Although respiratory symptoms are predominant in COVID-19, the cardiac pathology is of special interest because it increases both the risk of infection due to SARS-CoV-2 and the severity of the condition. Cardiac insufficiency is one of the most frequent and severe complications of SARS-CoV-2 because increases the death risk by causing rapidly progressive fulminant myocarditis (35). The cardiac problems can continue even after recovery, regardless of any preexisting condition, severity level and general course of the acute illness or time elapsed since the original diagnosis (71). The damage caused in severe cases of the disease is reflected in the elevation of biomarkers such as troponin I, CK-MB, BNP and myoglobin. Although during admission the values of these parameters are observed to be normal in mild and serious cases in patients, an exacerbated increase of these cardiac markers is observed in patients who subsequently die $(35,51)$. This is the case of troponin I, which in some more seriously ill patients increases during hospitalization and immediately before death (50). In contrast, certain markers are found higher in severe cases compared to mild cases but they usually do not exceed the reference values (Table II).

The elevation of serum levels of inflammatory markers is commensurate with the severity of the disease and in some cases increases up to 12 times the reference value, possibly being related to the direct damage to the hepatic tissue or as a secondary effect of the pharmacological treatment used during the hospitalization of patients that evolve toward liver injury (52). For this reason, it is recommended at least to determine the levels of ALT, bilirubin and albumin during the treatment of patients with hepatotoxic medication and those with preexisting hepatic conditions (72).

Also, the combination of eosinopenia and increased high-sensitivity C-reactive protein (hs-CRP) can serve to distinguish between patients suspected of presenting COVID-19 (supporting the diagnostic process) from patients with pneumonia or a respiratory infection similar to COVID-19 (73). Moreover, elevated $\mathrm{LDH}$ is one of the most frequently altered biochemical parameters on admission (15) and the increase of certain inflammatory cytokines (IL-2, IL-6, $\mathrm{TNF} \alpha$ ) during the progression stage (74) can contribute information to the follow-up of the disease (Table I). In prior cases of pneumonia caused by SARS-CoV infection (2003), it was found that the serum levels of pro-inflammatory cytokines (IFN- $\gamma$, IL1, IL-6, IL-12, and TGF-dv) and chemokines (CCL2, CXCL9, CXCL10 and IL-8) in patients infected with SARS-CoV were higher than in healthy patients, while the level of the cytokine synthesis inhibitory factor (IL10 ) in seriously ill patients was significantly lower than in healthy counterparts (75). In a meta-analysis of COVID-19, several differences were observed between groups of more severe cases. The non-survivors in comparison with the survivors had significant increases in their leukocyte, total bilirubin, creatine kinase, serum ferritin and interleukin 6 (IL-6) values and more significant decreases in their lymphocyte and platelet counts (76).

Concerning pancreatic function, an elevation of amylase and lipase has been associated with severe cases, which is consistent with pancreatic injury evidenced by computed tomography in seriously ill patients (65).

The literature analysis reveals several limitations, in that the evidence is still limited to one population and could thus exclude relevant factors associated with the epidemiological characteristics, the virulence of different strains, mutations in the viral genome, sociocultural behavior, and socioeconomic and hygiene-sanitary conditions of other regions that could influence on the impact of the disease in different populations (77). We hope that there will soon be more scientific evidence available to reflect these differences and sources of variability. Other limitations noted were that some of the studies analyzed $(22,23$, $31,33)$ did not include the reference ranges of their population (41), a follow-up of the biomarkers was not always carried out during the course of the hospitalization time, or there was no information available.

Interestingly, the use of other analytical technologies such as proteomic studies has enhanced the identification of potential biomarkers that express dif- 
ferentially depending on the severity of the clinical condition of COVID-19 patients, which include factors of the complement, coagulation factors, modulators of inflammation and pro-inflammatory factors. These findings, as a complement to the variations in classic laboratory parameters, could contribute to identify potential therapeutic targets against infectious agents (78).

Previous reports suggest that COVID-19 patients with different complications (inflammation, co-infection and thrombosis) can be categorized by analytical patterns, where personalized therapy could contribute to lower early mortality rates (OR 0.144 ; $\mathrm{Cl}$ : 0.03-0.686; $\mathrm{p}=0.015$ ) in patients, thus supporting the idea that each situation requires a therapeutic focus adjusted to the type of altered pattern (79).

In conclusion, clinical laboratories play a pivotal role in the SARS-CoV-2 pandemic, not only from a diagnostic point of view but also in terms of the prognosis of COVID-19 patients, determining the degree of metabolic disorder of the patients and favoring the development of support tools for clinical decision

\section{References}

1. Abuelgasim E, Saw $\sqcup$, Shirke M, Zeinah M, Harky A. COVID-19: Unique public health issues facing Black, Asian and minority ethnic communities. Mosby Inc 2020; p. 1-10.

2. Gorbalenya AE, Baker SC, Baric RS, de Groot RJ, Drosten C, Gulyaeva AA, et al. The species Severe acute respiratory syndrome-related coronavirus: classifying 2019-nCoV and naming it SARS-CoV-2. Nature Microbiology 2020; 5(4): 536-44.

3. Lai CC, Shih TP, Ko WC, Tang HJ, Hsueh PR. Severe acute respiratory syndrome coronavirus 2 (SARS-CoV-2) and coronavirus disease-2019 (COVID-19): The epidemic and the challenges. Elsevier B.V. 2020. p. 105924-

4. Estevão A. Artículo de opinión: COVID-19. Acta Radiológica Portuguesa 2020; 32(1): 1-5.

5. Hamming I, Timens W, Bulthuis MLC, Lely AT, Navis GJ, van Goor $\mathrm{H}$. Tissue distribution of ACE2 protein, the functional receptor for SARS coronavirus. A first step in understanding SARS pathogenesis. Journal of Pathology 2004; 203(2): 631-7.

6. Imai $Y$, Kuba K, Ohto-Nakanishi T, Penninger JM. Angiotensin-converting enzyme 2 (ACE2) in disease pathogenesis. Circ J 2010; 74(3): 405-10. Epub 2010/02/06.

7. Andersen KG, Rambaut A, Lipkin WI, Holmes EC, Garry RF. The proximal origin of SARS-CoV-2. Nature Research 2020; p. 450-2.

8. Loeffelholz MJ, Tang Y-W. Laboratory diagnosis of emerging human coronavirus infections - the state of the making in order to adjust the therapy to the biological changes experienced by the subjects. Likewise, the laboratory work allows optimizing the hospital environment resources of the critical units of the health systems, resulting in the enhancement of the response time and efficiency of this response (80). However, these approaches should be constantly reassessed based on new and reliable evidence published around the world, besides the incorporation of new technologies into the clinical laboratory work to obtain greater precision in the search for biochemical markers.

Acknowledgements: Supported by FEQUIP2019CS-05 and VIPUCT N²016PF-PL-04 grant from the Vicerrectoría de Investigación y Postgrado, Universidad Católica de Temuco.

\section{Conflict of interest statement}

All the authors declare that they have no conflict of interest in this work.

art. Emerging Microbes \& Infections 2020; 9(1): 74756.

9. Yan R, Zhang Y, Li Y, Xia L, Guo Y, Zhou Q. Structural basis for the recognition of SARS-CoV-2 by full-length human ACE2. Science 2020; 367(6485): 1444-8.

10. Xu J, Zhao S, Teng T, Abdalla AE, Zhu W, Xie L, et al. Systematic Comparison of Two Animal-to-Human Transmitted Human Coronaviruses: SARS-CoV-2 and SARS-CoV. Viruses 2020; 12(2): 1-17.

11. Ahn DG, Shin HJ, Kim MH, Lee S, Kim HS, Myoung J, et al. Current Status of Epidemiology, Diagnosis, Therapeutics, and Vaccines for Novel Coronavirus Disease 2019 (COVID-19). J Microbiol Biotechnol 2020; 30(3): 313-24. Epub 2020/04/03.

12. Chan JF, Yip CC, To KK, Tang TH, Wong SC, Leung KH, et al. Improved Molecular Diagnosis of COVID-19 by the Novel, Highly Sensitive and Specific COVID-19RdRp/Hel Real-Time Reverse Transcription-PCR Assay Validated In Vitro and with Clinical Specimens. J Clin Microbiol 2020; 58(5). Epub 2020/03/07.

13. Dong X, Cao Y-y, Lu X-x, Zhang J-j, Du H, Yan Y-q, et al. Eleven faces of coronavirus disease 2019. Allergy 2020; 0: 1-11.

14. Lian J, Jin X, Hao S, Jia H, Cai H, Zhang $X$, et al. Epidemiological, clinical, and virological characteristics of 465 hospitalized cases of coronavirus disease 2019 (COVID 19) from Zhejiang province in China. Influenza and Other Respiratory Viruses 2020; 0: 1-11.

15. Giuseppe L, Mario P. Laboratory abnormalities in patients with COVID-2019 infection in: Clinical Chemistry and 
Laboratory Medicine (CCLM) - Ahead of print. De Gruyter 2020: 1-4.

16. Kubina R, Dziedzic A. Molecular and Serological Tests for COVID-19. A Comparative Review of SARS-CoV-2 Coronavirus Laboratory and Point-of-Care Diagnostics. Diagnostics 2020; 10(6): 1-18.

17. Lippi G, Plebani M. The critical role of laboratory medicine during coronavirus disease 2019 (COVID-19) and other viral outbreaks. Clinical Chemistry and Laboratory Medicine 2020; 58(7): 1063-9.

18. Ramírez-Truque M, Herrera-Morice M. Rol del laboratorio clínico ante la epidemia del COVID-19: revisión de los métodos diagnósticos disponibles y sus limitaciones. Revista médica de Costa Rica 2020; 85(629): 73-80.

19. Sara F, Ruggieri Iván CN, Andrés CM, Eduardo CA, Esteban L. Seguimiento y tratamiento del paciente con COVID-19. 2020

20. Chousterman BG, Swirski FK, Weber GF. Cytokine storm and sepsis disease pathogenesis. Semin Immunopathol 2017; 39(5): 517-28. Epub 2017/05/31.

21. Hu B, Huang $S$, Yin L. The cytokine storm and COVID19. J Med Virol 2020. Epub 2020/06/28

22. Liu J, Li S, Liu J, Liang B, Wang $X$, Wang $H$, et al. Longitudinal characteristics of lymphocyte responses and cytokine profiles in the peripheral blood of SARS-CoV-2 infected patients. EBioMedicine 2020; 55: 1-9.

23. Huang C, Wang Y, Li X, Ren L, Zhao J, Hu Y, et al Clinical features of patients infected with 2019 novel coronavirus in Wuhan, China. The Lancet 2020; 395(10223): 497-506.

24. Qin C, Zhou L, Hu Z, Zhang S, Yang S, Tao Y, et al. Dysregulation of immune response in patients with COVID-19 in Wuhan, China. Clinical infectious diseases : an official publication of the Infectious Diseases Society of America 2020; 2019: 4-10.

25. Gong J, Dong H, Xia Q, Huang Z, Wang D, Zhao Y, et al. Correlation Analysis Between Disease Severity and Inflammation-related Parameters in Patients with COVID19 Pneumonia. medRxiv. 2020.

26. Ahnach M, Zbiri S, Nejjari S, Ousti F, Elkettani C. C-reactive protein as an early predictor of COVID-19 severity. J Med Biochem 2020; 39 (4) 500-7.

27. Tan C, Huang Y, Shi F, Tan K, Ma Q, Chen Y, et al. Creactive protein correlates with computed tomographic findings and predicts severe COVID-19 early. Journal of Medical Virology 2020(April): 1-7.

28. Liu W, Tao ZW, Wang L, Yuan ML, Liu K, Zhou L, et al. Analysis of factors associated with disease outcomes in hospitalized patients with 2019 novel coronavirus disease. Chinese Medical Journal 2020; 133(9): 1032-8.

29. Pepys MB, Hirschfield GM. C-reactive protein: a critical update. J Clin Invest 2003; 111(12): 1805-12. Epub 2003/06/19.

30. Kinoshita A, Onoda H, Imai N, Iwaku A, Oishi M, Tanaka $\mathrm{K}$, et al. The $\mathrm{C}$-reactive protein/albumin ratio, a novel inflammation-based prognostic score, predicts outcomes in patients with hepatocellular carcinoma. Ann Surg Oncol 2015; 22(3): 803-10. Epub 2014/09/06.
31. Fan Z, Chen L, Li J, Cheng X, Yang J, Tian C, et al Clinical Features of COVID-19-Related Liver Damage. Clinical Gastroenterology and Hepatology 2020; 18(7): 1561-6.

32. Wang D, Hu B, Hu C, Zhu F, Liu X, Zhang J, et al Clinical Characteristics of 138 Hospitalized Patients with 2019 Novel Coronavirus-Infected Pneumonia in Wuhan, China. JAMA - Journal of the American Medical Association 2020; 323(11): 1061-9.

33. Cheng $Y$, Luo R, Wang K, Zhang M, Wang Z, Dong L, et al. Kidney disease is associated with in-hospital death of patients with COVID-19. Elsevier B.V.; 2020. p. 829-38.

34. Li Z, Wu M, Guo J, Yao J, Liao X, Song S, et al. Caution on Kidney Dysfunctions of 2019-nCoV Patients. Cold Spring Harbor Laboratory Press, 2020.

35. Ruan Q, Yang K, Wang W, Jiang L, Song J. Clinical predictors of mortality due to COVID-19 based on an analysis of data of 150 patients from Wuhan, China. Intensive Care Med 2020; 46: 846-8.

36. Yuan J, Zou R, Zeng L, Kou S, Lan J, Li X, et al. The correlation between viral clearance and biochemical outcomes of 94 COVID-19 infected discharged patients. Inflamm Res. 2020; 69(6): 599-606. Epub 2020/04/01.

37. McGonagle D, Sharif K, O'Regan A, Bridgewood C. The Role of Cytokines including Interleukin-6 in COVID-19 induced Pneumonia and Macrophage Activation Syndrome-Like Disease. Autoimmunity Reviews 2020.

38. Zhou F, Yu T, Du R, Fan G, Liu Y, Liu Z, et al. Clinical course and risk factors for mortality of adult inpatients with COVID-19 in Wuhan, China: a retrospective cohort study. The Lancet 2020; 395(10229): 1054-62.

39. Mehta P, McAuley DF, Brown M, Sanchez E, Tattersall RS Manson JJ. COVID-19: consider cytokine storm syndromes and immunosuppression. The Lancet 2020; 395(10229): 1033-4

40. Velavan TP, Meyer CG. Mild versus severe COVID-19: Laboratory markers. International Journal of Infectious Diseases 2020; 95: 304-7

41. Chen N, Zhou M, Dong X, Qu J, Gong F, Han Y, et al. Epidemiological and clinical characteristics of 99 cases of 2019 novel coronavirus pneumonia in Wuhan, China: a descriptive study. The Lancet 2020; 395(10223): 50713.

42. Liu Y, Yang Y, Zhang C, Huang F, Wang F, Yuan J, et al. Clinical and biochemical indexes from 2019-nCoV infected patients linked to viral loads and lung injury. Science China Life Sciences 2020; 63(3): 364-74.

43. Zhao D, Yao F, Wang L, Zheng L, Gao Y, Ye J, et al. A comparative study on the clinical features of COVID-19 pneumonia to other pneumonias. Clinical infectious diseases : an official publication of the Infectious Diseases Society of America 2020: 1-6.

44. Zhang Jj, Dong $X$, Cao Yy, Yuan Yd, Yang Yb, Yan Yq et al. Clinical characteristics of 140 patients infected with SARS-CoV-2 in Wuhan, China. Allergy: European Journal of Allergy and Clinical Immunology 2020; 00: $1-12$ 
45. Salbach C, Giannitsis E. Cardiac biomarkers and COVID19 - Phenotypes and Interpretation. Deutsche Medizinische Wochenschrift 2020; 145(11): 755-60.

46. Perico L, Benigni A, Remuzzi G. Should COVID-19 Concern Nephrologists? Why and to What Extent? the Emerging Impasse of Angiotensin Blockade. S. Karger AG; 2020. p. 213-21.

47. López-Ponce de León JD, Cárdenas-Marín PA, GiraldoGonzález GC, Herrera-Escandón Á. COVID-19 coronavirus: More than just a lung disease: what it is and what we know about the link with the cardiovascular system. Revista Colombiana de Cardiologia 2020.

48. Oudit GY, Kassiri Z, Jiang C, Liu PP, Poutanen SM, Penninger JM, et al. SARS-coronavirus modulation of myocardial ACE2 expression and inflammation in patients with SARS. European Journal of Clinical Investigation 2009; 39(7): 618-25.

49. Li JW, Han TW, Woodward M, Anderson CS, Zhou H, Chen YD, et al. The impact of 2019 novel coronavirus on heart injury: A Systematic review and Meta-analysis. Progress in Cardiovascular Diseases 2020: 1-7.

50. Churchill TW, Bertrand PB, Bernard S, Namasivayam M, Churchill J, Crousillat D, et al. Echocardiographic Features of COVID-19 Illness and Association with Cardiac Biomarkers. Mosby Inc.; 2020.

51. Deng Q, Hu B, Zhang Y, Wang H, Zhou X, Hu W, et al. Suspected myocardial injury in patients with COVID-19: Evidence from front-line clinical observation in Wuhan, China. International Journal of Cardiology 2020; 311: 116-21.

52. Cai Q, Huang D, Yu H, Zhu Z, Xia Z, Su Y, et al. COVID19: Abnormal liver function tests. Journal of Hepatology 2020: 1-9.

53. Xu Z, Shi L, Wang Y, Zhang J, Huang L, Zhang C, et al. Pathological findings of COVID-19 associated with acute respiratory distress syndrome. The Lancet Respiratory Medicine 2020; 8(4): 420-2.

54. Zhang C, Shi L, Wang FS. Liver injury in COVID-19: management and challenges. Elsevier Ltd; 2020. p. 428-30.

55. Feng G, Zheng KI, Yan Q-Q, Rios RS, Targher G, Byrne CD, et al. COVID-19 and Liver Dysfunction: Current Insights and Emergent Therapeutic Strategies. Journal of Clinical and Translational Hepatology 2020; 8(1): 1-7.

56. Farcas Gabriella A, Poutanen Susan M, Mazzulli T, Willey Barbara M, Butany J, Asa Sylvia L, et al. Fatal Severe Acute Respiratory Syndrome Is Associated with Multiorgan Involvement by Coronavirus. The Journal of Infectious Diseases 2005; 191(2): 193-7.

57. Angel-Korman A, Brosh T, Glick K, Leiba A. COVID-19, The Kidney and Hypertension 2020. p. 231-4.

58. Diao B, Wang C, Wang R, Feng Z, Tan $Y$, Wang $H$, et al. Human Kidney is a Target for Novel Severe Acute Respiratory Syndrome Coronavirus 2 (SARS-CoV-2) Infection Running title: SARS-CoV-2 infects human kidney. medRxiv. 2020: 1-17.

59. Zhou H, Zhang Z, Fan H, Li J, Li M, Dong $Y$, et al. Urinalysis, but not blood biochemistry, detects the early renal-impairment in patients with COVID-19. medRxiv. 2020: 1-19.

60. Zhang G, Zhang J, Wang B, Zhu X, Wang Q, Qiu S. Analysis of clinical characteristics and laboratory findings of 95 cases of 2019 novel coronavirus pneumonia in Wuhan, China: A retrospective analysis. Respiratory Research 2020; 21(1): 74.

61. Wang Q, Zhao H, Liu LG, Wang YB, Zhang T, Li MH, et al. Pattern of liver injury in adult patients with COVID-19: a retrospective analysis of 105 patients. Military Medical Research 2020; 7(28): 1-8.

62. Wang F, Wang $H$, Fan J, Zhang $Y$, Wang $H$, Zhao Q. Pancreatic Injury Patterns in Patients With Coronavirus Disease 19 Pneumonia. Gastroenterology 2020; 159(1): 367-70.

63. Patel KP, Patel PA, Vunnam RR, Hewlett AT, Jain R, Jing $R$, et al. Gastrointestinal, hepatobiliary, and pancreatic manifestations of COVID-19. Journal of Clinical Virology 2020; 128: 1-5.

64. Yang JK, Lin SS, Ji XJ, Guo LM. Binding of SARS coronavirus to its receptor damages islets and causes acute diabetes. Acta Diabetol 2010; 47(3): 193-9. Epub 2009/04/01.

65. Liu F, Long X, Zhang B, Zhang W, Chen X, Zhang Z. ACE2 Expression in Pancreas May Cause Pancreatic Damage After SARS-CoV-2 Infection. Clinical Gastroenterology and Hepatology 2020; 18: 2128-30.

66. Hadi A, Werge M, Kristiansen KT, Pedersen UG, Karstensen JG, Novovic S, et al. Coronavirus Disease-19 (COVID-19) associated with severe acute pancreatitis: Case report on three family members. Pancreatology 2020; 20: 665-7.

67. Cheung KS, Hung IFN, Chan PPY, Lung KC, Tso E, Liu $\mathrm{R}$, et al. Gastrointestinal Manifestations of SARS-CoV-2 Infection and Virus Load in Fecal Samples From a Hong Kong Cohort: Systematic Review and Meta-analysis. Gastroenterology 2020; 159(1): 81-95. Epub 2020/ 04/07.

68. De-Madaria E, Siau K, Cárdenas-Jaén K. Increased amylase and lipase in patients with COVID-19 pneumonia: don t blame the pancreas just yet! 2020.

69. Xiang J, Wen J, Yuan X, Xiong S, Zhou XUE, Liu C, et al. Potential biochemical markers to identify severe cases among COVID-19 patients. medRxiv 2020: 2020.03.19.20034447-2020.03.19.

70. Riera ARP. Los marcadores de muerte en la COVID-19. 2020.

71. Puntmann VO, Carerj ML, Wieters I, Fahim M, Arendt C, Hoffmann J, et al. Outcomes of Cardiovascular Magnetic Resonance Imaging in Patients Recently Recovered From Coronavirus Disease 2019 (COVID19). JAMA Cardiology 2020; 2019: 1-9.

72. Thompson S, Bohn MK, Mancini N, Loh TP, Wang CB, Grimmler $M$, et al. IFCC interim guidelines on biochemical/hematological monitoring of COVID-19 patients. Clin Chem Lab Med 2020. Epub 2020/10/08.

73. Li Q, Ding X, Xia G, Chen HG, Chen F, Geng Z, et al. Eosinopenia and elevated C-reactive protein facilitate 
triage of COVID-19 patients in fever clinic: A retrospective case-control study. EClinicalMedicine 2020; 23: 17.

74. Hernández A, Papadakos PJ, Torres A, González DA, Vives $M$, Ferrando $C$, et al. Two known therapies could be useful as adjuvant therapy in critical patients infected by COVID-19. Revista Espanola de Anestesiologia y Reanimacion 2020; 67(5): 245-52.

75. Wong CK, Lam CWK, Wu AKL, Ip WK, Lee NLS, Chan IHS, et al. Plasma inflammatory cytokines and chemokines in severe acute respiratory syndrome. Clinical and Experimental Immunology 2004; 136(1): 95-103.

76. Henry BM, de Oliveira MHS, Benoit S, Plebani M, Lippi G. Hematologic, biochemical and immune biomarker abnormalities associated with severe illness and mortality in coronavirus disease 2019 (COVID-19): a meta-analysis. Clin Chem Lab Med 2020; 58(7): 1021-8. Epub 2020/04/15.
77. Yamamoto N, Bauer G. Apparent difference in fatalities between Central Europe and East Asia due to SARSCOV-2 and COVID-19: Four hypotheses for possible explanation. Med Hypotheses 2020; 144: 110160. Epub 2020/08/17.

78. Messner CB, Demichev V, Wendisch D, Michalick L, White $M$, Freiwald $A$, et al. Ultra-High-Throughput Clinical Proteomics Reveals Classifiers of COVID-19 Infection. Cell Systems 2020; 11(1): 11-24.

79. Stankovic B, Kotur N, Gasic V, Klaassen K, Ristivojevic B, Stojiljkovic M, Pavlovic S, Zukic B. Pharmacogenomics landscape of COVID-19 therapy response in Serbian population and comparison with worldwide populations. J Med Biochem 2020; 39(4): 488-99.

80. Lippi G, Plebani M. The critical role of laboratory medicine during coronavirus disease 2019 (COVID-19) and other viral outbreaks. Clin Chem Lab Med 2020; 58(7): 1063-9. Epub 2020/03/20.

Received: November 11, 2020

Accepted: November 24, 2020 